\title{
Ultrasound guided chronic pain interventions (Part II)
}

\author{
Ultrason eşliğinde kronik ağrı girişimleri (2. bölüm)
}

\author{
Taylan AKKAYA, Alp ALPTEKIN, Derya ÖZKAN
}

\begin{abstract}
Summary
Henceforth, ultrasonography (US) is an indispensible imaging technique in regional anesthesia practice. With the guidance of US, various invasive interventions in chronic pain pathologies of the musculoskeletal system, peripheral and neuroaxial pathologies has become possible. The management includes diagnostic blocks as weel as radiofrequency ablation and institution of neurolythic agents. During these algologic interventions we are able to see the target tissue, the dispersion of the drug and all nearby vascular structures. Besides these the US also protects the team from ionic radiation that one encounters when using flouroscopy of computed tomography. Latest publication in this field show that applicability of US in chronic pain syndromes is rapidly expanding with a good future. The additional equipment (echogenic needles, 3-D US etc.) will also expands its applications in algology practice. This review highlights different applications of US in chronic pain conditions.
\end{abstract}

Keywords: Chronic pain; nerve blocks; ultrasound.

\begin{abstract}
Özet
Artık rejyonal anestezi pratiğinde ultrasonografi (US) vazgeçilmez yardımcı görüntüleme tekniği olarak yerini almıştır. Ultrasonografi ile kas/iskelet, periferik ve nöraksial bölgelerin kronik ağrılı patolojilerde çeşitli invaziv girişimler yapmak olasıdır. Bu girişimler diagnostik bloklar, radyofrekans uygulamaları ve nörolitik ajanların uygulamaları olarak özetlenebilirler. Algolojik girişimler esnasında US; hedef dokuların görüntülenmesinde, uygulanan ilacın yayılımında, çevredeki vasküler yapıların görüntülenmesinde büyük kolaylıklar sağlar. Ayrıca US ile floroskopi ve bilgisayarlı tomografi uygulamaları esnasındaki radyasyon yayılımı söz konusu değildir. Kronik ağrı girişimlerinde US ile yayınlanan klinik çalışmalar umut vericidir. Ayrıca son yıllarda bu alandaki gelişmeler (ekojen iğneler, üç boyutlu US cihazları vd.) US'nin algoloji pratiğindeki kullanımının daha da yaygınlaşacağını düşündürmektedir. Bu derlemenin amacı, US eşliğinde yapılan çeşitli kronik ağrı girişimlerini gözden geçirmektir.
\end{abstract}

Anahtar sözcükler: Kronik ağrı; sinir blokları; ultrason.

\section{Neuroaxial interventions \\ Cervical negion}

During interventions that are performed on cervical region, a slight error in the needle localization can lead to dire complications. Shooting more images with fluoroscope to ensure correct localization means greater radiation exposure. One of the most important advantages of US is that this situation is not a problem to worry about. ${ }^{[1]}$ Another advantage of US in interventions at cervical region is that the procedure is completed in a shorter time compared to fluoroscopy and tomography. ${ }^{[2,3]}$ During fluoroscopy guided cervical medial branch blockade, there may be vascular structures on the needle path that can possibly get injured. ${ }^{[4]}$ Chance of accidental intravascular injection during fluoroscopy guided cervical region injections has been reported as $7 \% \cdot{ }^{[5]}$ Narouze emphasized that while fluoroscopy can detect intravascular injection, US can prevent it. ${ }^{[6]}$

At the level of cervical vertebra clear identification of structures with US is not easy, and it requires experience which takes time. Sonoanatomical description of cervical $6^{\text {th }}$ and $7^{\text {th }}$ vertebra has been first made by Martinoli et al. ${ }^{[7]} \mathrm{C} 5, \mathrm{C} 6$ and $\mathrm{C} 7$ transverse processes and differences in tubercle structures can be useful

Department of Anesthesiology, Pain Service, Dışkapı Yıldırım Beyazıt Training and Research Hospital, Ankara, Turkey

Submitted: 12.06.2015 Accepted after revision: 29.09.2015

Correspondence: Dr. Taylan Akkaya. Dışkapı Yıldırım Beyazıt Eğitim ve Araştırma Hastanesi, Anesteziyoloji Kliniği, Ağıı Servisi, Ankara, Turkey. Tel: +90 - 312 - 5962551 e-mail: dr.taylanakkaya@gmail.com

(c) 2016 Turkish Society of Algology 
in ultrasonographic identification of the area during cervical interventions.

At transverse imaging, marked anterior tubercle of $\mathrm{C} 6$ vertebra, called Chassaignac tubercle is characterized with its sharp structure, and it can easily be differentiated from C7 vertebra. C7 vertebra can be identified with its marked posterior tubercle and rudimentary anterior tubercle. Also at C7 level, vertebral artery is not inside transverse foramen yet. ${ }^{[8]}$ When US probe is shifted upwards, anterior and posterior tubercles of $\mathrm{C} 3, \mathrm{C} 4$ and $\mathrm{C} 5$ vertebrae are typically similar in size.

For interventions at upper levels (interventions related to TON, GON, C1-C2 joints), scanning from occiput toward C1 and C2 can be made with both transverse and long axis imaging. At the occipital region, occipital bone can be identified with transverse imaging. When moved caudally, first $\mathrm{C} 1$ and then $\mathrm{C} 2$ that has the first bifid process is visualized. If the probe is shifted slight laterally, first the lamina and then more laterally, articular pillar is visualized. During long axis imaging of occipital region, if transducer is placed vertically at the median line, to be over spinous processes, $\mathrm{C} 1$ spinous process is observed as rudimentary or it cannot be visualized at all. Transverse imaging of this region is recommended for occipital nerve blockade and C1-C2 joint injections, and long axis imaging is mainly recommended for cervical facet joint injections and medial branch blockades $^{[6]}$ (Figure 1).

If the procedure will be made at upper levels and on single side, mastoid process can be useful for level detection. ${ }^{[9]}$ When the probe is placed longitudinally just under mastoid protuberance, mastoid protuberance, $\mathrm{C} 1$ transverse process and vertebral artery can be visualized; when shifted slight caudally, vertebral artery disappears inside C2 transverse process (foramen). When lower part of the probe is rotated slightly to posterior (slightly oblique), C2-3 articulation can be observed. Moving caudally, facet joints at lower levels can be visualized.

Cervical facet joint injection: Obernauer et al. compared guidance of US and tomography in cervical facet joint injections in their randomized study including 40 patients, they determined procedure time was shorter in US group, and there was signifi-

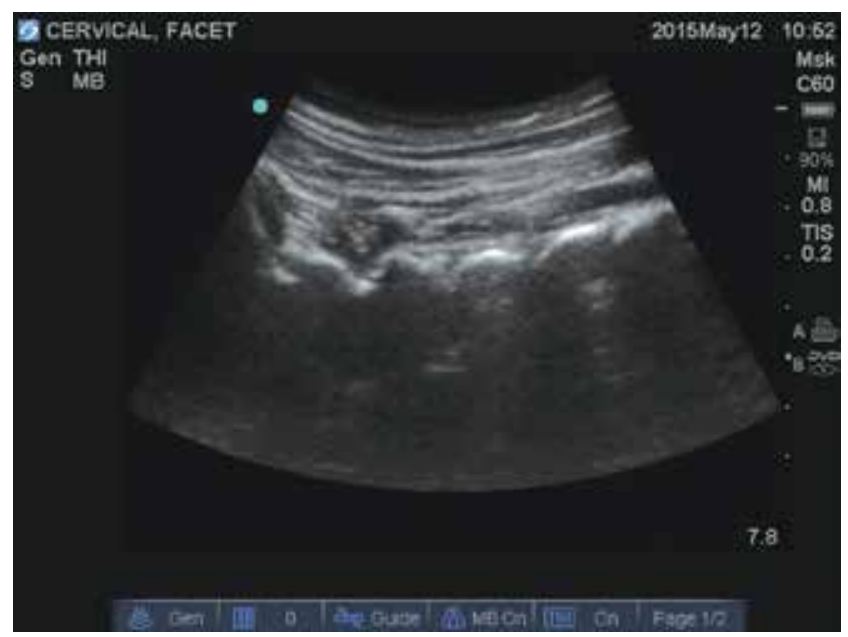

Figure 1. Apperance of cervical facet joints.

cant difference in repositioning requirement in favor of US. ${ }^{[3]}$ Narouze recommends transverse imaging for single-sided, single level injection, and lateral longitudinal imaging for injections at multiple levels. This imaging allows visualization of multiple levels at the same time. To shorten the distance of needle's path, it can be advanced out of plane ${ }^{[9]}$ Due to important vascular structures at the cervical region, advancing in plane may be safer for performers without sufficient experience.

When a low frequency prone is used at the median line, images of more vertebrae can be visualized at the same time on the same plane. Another advantage of this approach is that there is no requirement to reposition the patient in bilateral interventions. ${ }^{[10]}$ Occiput, C1 and C2 spinous processes provide guidance for level determination. When moved slightly to the lateral, first the laminar and then facet column and articular gap more laterally as an anechoic structure between the hyperechoic articular processes are identified. Injection is performed in plane from caudal to cranial direction. It is not possible to observe intraarticular injection with US, periarticular injection is recommended. ${ }^{[11]}$

Cervical medial branch blockade: C3 dorsal ramus divides into two as deep and superficial medial branches. Superficial branch is called third occipital nerve (TON), and it innervates $\mathrm{C} 2-3$ facet joint. Eichenberger et al. described bilateral ultrasonographic imaging of third cervical nerve (TON), which is the nerve of C2-3 facet joint, in transverse plane in 14 cases and performed blockade under US guidance. Researchers determined nerve observation 
rate was $86 \%$, correct positioning rate of the needle was $82 \%$ and blockade success rate was $90 \%{ }^{[12]}$

In their experimental study investigating visualization of cervical facet nerves with US, they determined that TON was observed at the highest rate (96\%) and C7 medial branch was observed at the lowest rate (32\%). In their clinical study in which TON blockade was performed either with US or fluoroscopy, Finlayson et al. reported that the nerve was visualized at $80 \%$ of the US group, and procedure time was shorter; vascular injury was detected at $10 \%$ of fluoroscopy group, there was no difference in pain scores of patients being followed up following the procedure in different groups. ${ }^{[13]}$

In order to visualize TON, while using a high frequency prone at lateral longitudinal plane, level determination is made starting from the mastoid process; it is recommended to perform the application by visualizing the nerve at the peak point of $\mathrm{C} 2-3$ facet joint surface. ${ }^{[9]}$

For cervical medial branch blockade, while using a high frequency probe at longitudinal plane, C2-3 facet joint level is detected by starting from mastoid process again as in TON imaging method, shifting toward $\mathrm{C} 1$ first and then more caudally. Facet joints are observed at this plane as "hills" lying next to each other. Medial branches (except TON) appear between these hills at the base. Moving caudally, level is determined, medial branch is identified at the most hollow region between two facet joints. Small vascular structures can be confused with neural appearance, so that Doppler technique should be used.

\section{Stellate ganglion blockade}

Stellate ganglion blockade is a valuable diagnostic and treatment method in pain with sympathetic origin at head, neck and upper extremity. In order to increase reliability and effectiveness of the method, conversion to fluoroscopic method from blind method has been done within years, and recently applications have been made under US guidance. Classically, stellate ganglion blockade is perform with paratracheal method at the level of anterior tubercle of C6 vertebra. Since anatomical structures cannot be adequately identified with blind method or with fluoroscopy, there is a risk of injury to the eu- sophagus, thyroid, inferior thyroid artery and risk of hematoma. Fluoroscopy allows identification of only C6 and C7 transverse processes. However, needle should be ideally located anterolateral to longus colli muscle, deep to the paravertebral fascia (to avoid extent along carotid sheath), but over the fascia (to avoid intramuscular injection). Determination of correct fascia is possible with US, thus, an effective sympathetic blockade can be performed while using a lower volume of local anesthetic. Possible hoarseness related with suprafascial dissemination in stellate ganglion blockade is reported to occur less with US guidance. ${ }^{[14]}$

US can increase safety of the technique by allowing direct visualization of vascular structures and soft tissues, and it can decrease risk of tissue injury. ${ }^{[15]} \mathrm{Im}$ portant anatomical structures are identified at transverse plane with a high frequency probe. Doppler technique would be useful to differentiate vascular structures enroute the determined path while advancing the needle. Injection is made on the surface of longus colli muscle deep to paravertebral fascia.

\section{Thoracic region}

Thoracic epidural procedures are excellent anesthetic and analgesic methods in thoracic and abdominal surgical interventions, they have favorable postoperative effects especially like reduction of pulmonary complications. Accurate determination of the level is essential for the application to be effective and have less side effects. ${ }^{[16]}$ Mainly two anatomical landmarks are used for level determination at cervicothoracic region; these are spinous process of thoracic $7^{\text {th }}$ vertebra that passes under lower tip of scapula and C7 spinous process that is also called vertebra prominence. ${ }^{[17]}$ However, level determination using these superficial landmarks may not always be accurate. ${ }^{[18]}$ In their study investigating the effectiveness of US for determination of these levels, Arzola et al. reported that level determination with superficial landmarks was not always accurate and utilization of US would be more appropriate. ${ }^{[19]}$

Thoracic epidural procedures provide some advantages over other methods for the treatment of pain following thoracic and upper abdominal surgery. However, difficulties may arise during their application especially at middle and upper levels, due to 
laminae and spinous processes overlapping each other. Evaluation of thoracic spinal anatomy and determination of epidural distance prior to thoracic epidural application would increase success rate. Tomography and MRI methods have been used to evaluate thoracic spinal anatomy and determine epidural distance, but these techniques are not very practical. ${ }^{[20]}$ On the other hand, US is a more accessible method.

In their report describing sonoanatomy at thoracic spinal region, Avramescu et al. stated they obtained conclusive images at lower thoracic levels in the rate of $98 \%$, but at upper levels, this success rate decreased; they reported that paramedian sagittal oblique imaging was more conclusive at upper levels compared to transverse imaging. ${ }^{[21]}$

\section{Lumbar region}

During daily practice, lumbar epidural injections are usually performed without using an imaging technique apart from patients who are overweight and have history of lumbar operation. However, current guidelines on chronic pain treatment recommend use of imaging techniques (fluoroscopy) preferably during interlaminar injections, and absolutely during transforaminal injections. ${ }^{[22]}$ Karmakar et al. used "water based spine phantom" model for understanding spinal anatomy, and they reported paramedian sagittal axis provided better images for visualization of neuroaxial anatomy. Low frequency convex probes capable of penetrating deep are preferred in sonographic examination of lumbar region, since anatomical structure are located deeper. Another advantage of this probe is wider view that it provides for deeper structures, making it easier to track advancing of the needle in real-time with US in central neuroaxial blockades. ${ }^{[23]}$ However, linear probes may be preferred for evaluation of superficial structures like spinous processes, especially in lean patients. Longitudinal median imaging is useful for evaluation of spinous processes, and also for determination of vertebral level. When probe is placed longitudinally at the median line along spinous processes, spinal processes align up in serially as a hyperechoic line. One of the most appropriate methods for determining vertebral level is to localize sacrum, which is an uninterrupted hyperechoic line, and to identify L5S1 interspinous space at the cranial side.
Posterior vertebral elements can be visualized at the level of spinous processes at transverse plane. Spinous processes can be observed at the middle as hyperechoic convex line; deeper at its both sides, laminae can be observed as hyperechoic lines, and lateral to laminae, facet joints can be visualized between two bone structures as hypoechoic areas. Transverse processes are located deeper and laterally as hyperechoic structures. By moving the probe between two spinous processes, acoustic shadowing can be casted aside exposing the spinal canal. Just above posterior dura, which is observed as hyperechoic, epidural space is observed as having less echogenicity compared to dura.

During paramedian sagittal scanning at lumbar region, the first bone structure observed is lamina; bone structure delays passage of US wave, so acoustic shadow is onserved under lamina. Between acoustic shadows, there is a gap (acoustic window) where neuroaxial structures in spinal canal can be visualized. Within this acoustic window, ligamentum flavum is observed as an hyperechoic band between laminae. Below ligamentum flavum, posterior dura is seen as hyperechoic structure, epidural space is located between these two structures as hypoechoic region that is several $\mathrm{mm}$ in size. Although ligamentum flavum and posterior dura are hyperechoic, dura can be visualized better compared to ligamentum flavum. ${ }^{[24]}$ Karmakar reported the distance between skin and lamina as $2.54 \mathrm{~cm}$, and the distance between skin and posterior dura as $3.19 \mathrm{~cm}$ in paramedian sagittal US examination of lumbar region in non-overweight young adults. ${ }^{[24]}$

During longitudinal imaging, when moved to the level of facet joints, they can appear as lump. Joint capsule covers the joint as an anechoic line. When the probe is moved vertically to $6-7 \mathrm{~cm}$ lateral from the spinous processes, deep to the hypoechoic muscle appearance transverse processes line up as hyperechoic convex structures (Figure 2).

In US guided epidural interventions, an assistant is required in order to observe advance of the needle. However, Karmakar proposed the procedure could be performed by one performer alone using a special LOR injector (Episure ${ }^{\circledast}$ ) that assists in identification of epidural area. ${ }^{[23]}$ During US guided interlami- 


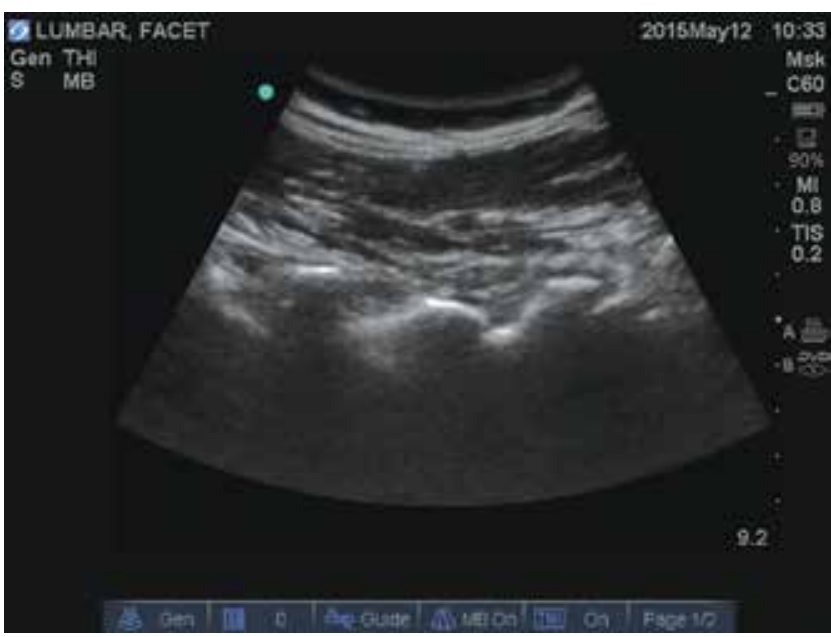

Figure 2. Apperance of lumbar facet joints.

nar epidural injections, advancing the needle in interlaminar space is not as easy as in fluoroscopic methods. Epidural space is visualized better at paramedian sagittal position. ${ }^{[25]}$

Studies comparing US, fluoroscopy and tomography with regard to required time for level determination during interventions report different success rates. ${ }^{[3]}$ However, it is thought that whether US or fluoroscopy is used for interlaminar epidural application procedure has no effect on completion time, and that USG would not take the place of fluoroscopy. ${ }^{[26]}$

\section{Facet joint injection}

The first case series involving US guided facet joint injection belongs to Kullmer et al. in 1997. ${ }^{[27]}$ In their cadaver study in which facet joint injection was performed with US guidance and confirmed with fluoroscopy, Gofeld et al. stated that US could be an alternative imaging method to fluoroscopy and tomography. ${ }^{[28]}$ In another prospective randomized study involving 40 patients, US guided lumbar facet joint injection was compared to a group in which injection was made with tomography, and US group was determined to be more favorable regarding radiation exposure and procedure time, and no difference was found with regard to pain palliation. ${ }^{[29]}$

During US guided facet joint injection, target vertebra level is determined by longitudinal scanning in the first place. Next, injection is performed after visualization of the space between facet joints which is between superior and inferior articular processes of lumbar vertebrae, by transverse imaging (Figure 3).

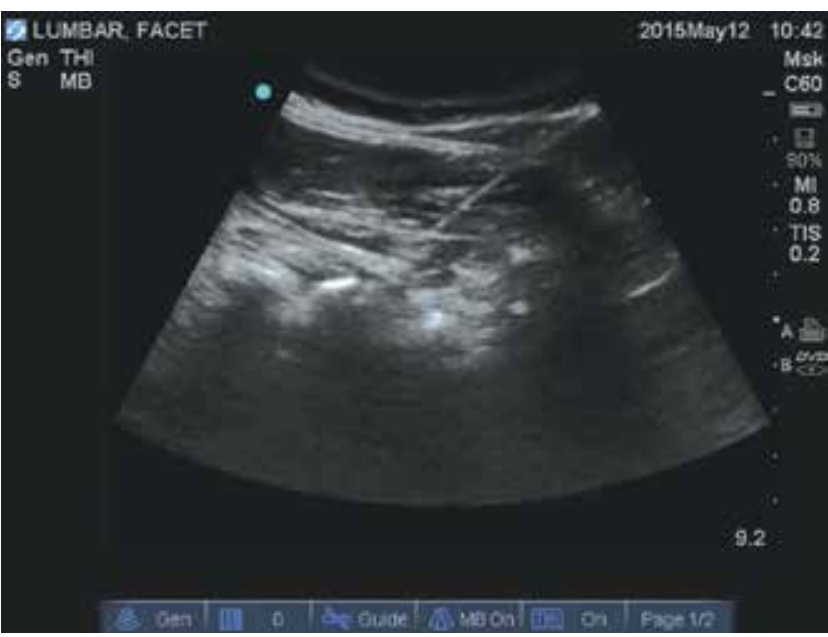

Figure 3. Lumbar facet joint injection.

\section{Lumbar medial branch blockade}

Selective blockade of sensorial nerves is commonly performed in pain clinics for diagnosis of lumbar facet pain. Medial branches of dorsal rami of lumbar nerves is located at the region between transverse process and superior articular process. Dorsal ramus for L5 vertebra level is targeted, and injection is performed at sacral alar region.

In one cadaveric study in which needle localization was confirmed with $C T$, it was reported that in 45 out of 50 facet injections targeted region was reached, and in remaining 5 injections the needle was $5 \mathrm{~cm}$ away from targeted region. ${ }^{[30]}$ In another study, US guided lumbar medial branch blockade application was controlled with fluoroscopy and in 96 out of 101 cases the needle was in correct position and in 2 cases intravascular injection was observed. ${ }^{\left[{ }^{[1]}\right.}$ Lumbar Medial branch blockade with US guidance may be difficult in the presence of degenerative changes in vertebrae and if patient's body mass index (BMI) is high. Ruach et al. performed US guided lumbar medial branch blockade in obese patients, and reported $62 \%$ success rate and stated that the procedure could not be done accurately in obese patients with US alone. ${ }^{[32]}$ Low frequency and curved probe is preferred for lumbar medial branch blockade. First, sacrum and $L 5$ vertebra are identified, targeted vertebra level is identified by scanning in longitudinal plane towards cranially. Graham et al. described lumbar medial branch blockade in transverse imaging. Observed structures from medial to lateral are spinous process, lamina, articular process and transverse process, respectively. The needle is advanced 


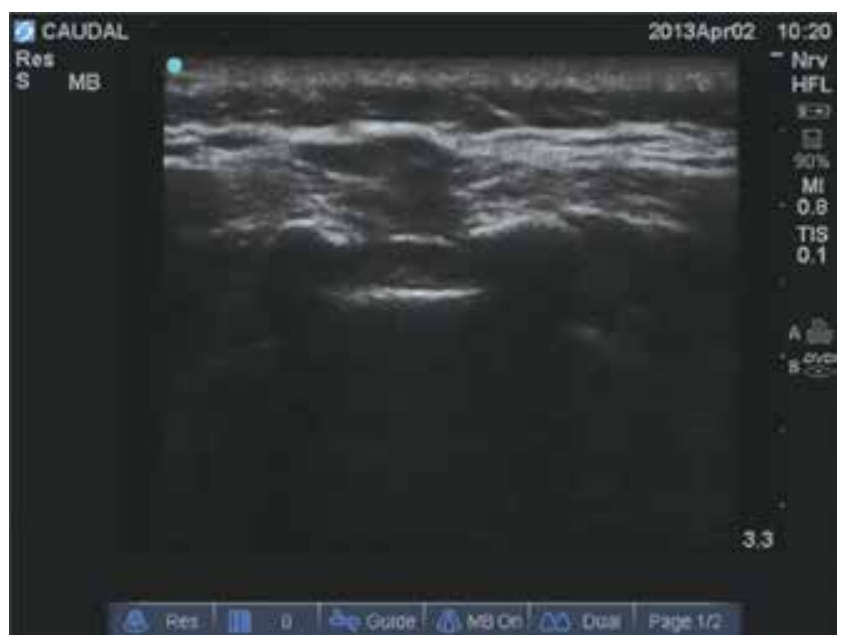

Figure 4. Caudal epidural space.

from lateral to medial in plane, it should contact with bone at the junction area of transverse process and inferior part of superior articular process. Next, switching to longitudinal plane, the tip of the needle is confirmed to superior to transverse process (to avoid nerve root injury). Iliac wing may prevent lateral entry at L5-S1 level, necessitating out of plane method. ${ }^{[33]}$

\section{Periradicular injections}

Utilization of US in interlaminar epidural injections was studied especially in obstetric patients, favorable results were reported for determination of median line and epidural space. However, utilization of US as a single imaging method in transforaminal epidural and nerve root injections is not a widely accepted practice yet. The main reasons for this are not being able to visualize needle and distribution of injected drug, and the difficulty in detection of intravascular injection.

It is quite difficult to visualize lumbar nerve roots with US. Lozides et al. performed injection to pararadicular area near lumbar intertransverteral ligament that can be detected with US in a cadaveric study; after controlling with fluoroscopy, they determined that the needles were in correct position and contrast agent diffused around the targeted nerve root. ${ }^{[34]}$

In one study including 40 patients in which US guided periradicular injection was performed, when needle localizations were controlled with $\mathrm{CT}$, it was determined that the needle was in correct position in $90 \%$ ratio, and US was more favorable regarding needle placement time. ${ }^{[35]}$

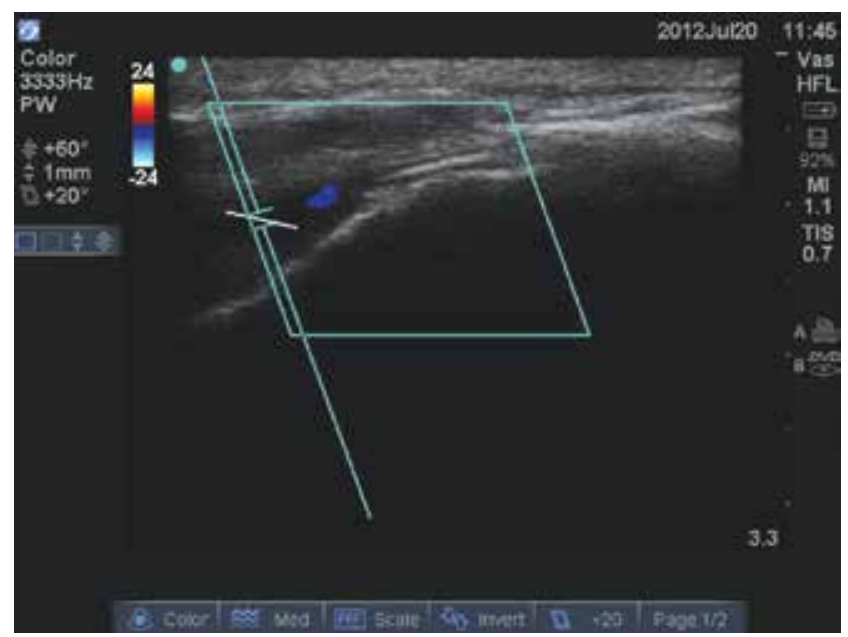

Figure 5. Caudal epidural injection.

US has the potential to contribute in detection of important vascular structures at neuroforamen area; however, the performer should be quite experienced for this. Today, fluoroscopy still holds its important place as the preferred imaging method in transforaminal injections. ${ }^{[33]}$

\section{Caudal injections}

Due to commonly observed variations in sacral anatomy, caudal blockades performed with blind methods have low success rates. ${ }^{[33]}$ Sacral hiatus and caudal space can easily be visualized with US at median sagittal plane, allowing caudal epidural injections in realtime (Figure 4). US guided caudal injections are reported to be fast, easy and have high success rates. ${ }^{[36]}$

During US guided caudal blockade, sacrococcygeal ligament and sacral hiatus are identified at transverse plane, sacral space is observed between sacral horns, and sacrum is found beneath it. Needle is placed in transverse position out of plane, and its advance is followed in plane. It may not be easy to follow its advance due to shadowing of the bone structure (Figure 5).

\section{Sacroiliac joint injection}

Success rate of blind sacroiliac joint injections is approximately $22 \% \cdot{ }^{[33]}$ In one study evaluating US guided injection in 60 cases, success rate was $60 \%$ for the first 30 cases, whereas it was reported to be $93.5 \%$ for the next 30 cases. $^{[37]}$ In another study involving US guided sacroiliac joint injection in twenty cadavers, 9 out of 10 injections made at the level of S2 foramen level were successful, whereas 7 out of 10 injections at the level of $\mathrm{S} 1$ foramen were successful. ${ }^{[38]}$ 
It is possible to perform arthrogram with fluoroscopy, however it is difficult to detect intraarticlar injections or needle localization with US, iatrogenic injury may happen to joint cartilage. Therefore, periarticular area should be preferred for US guided injections. ${ }^{[33]}$

In one study, US guided steroid injection was performed in 20 patients with sacroileitis and controlled with MRI; it was shown to be in joint space only in $40 \%$ of the cases, however, there was no difference with regard to pain palliation. ${ }^{[39]}$

In prone position, using a low frequency probe, sacral hiatus and lateral borders of the sacrum are identified with transverse imaging in the prone positioned patient, an hypoechoic gap between sacrum and ileum is determined, and this gap is traced to be continuing upwards. The needle is guided from medial to lateral at inferior border of the joint at the level of S2 foramen. The joint may be in fibrotic structure at upper levels.

In conclusion, utilization of US in chronic pain treatment may be regarded as to be at its initial stages. Anatomical studies related to some interventions are still being performed. There are not sufficient large series or prospective randomized clinical studies related with many interventions yet. On the other hand, there is an accelerated advancement in US technology. Transducers and scanning schemes have improved and three and four dimensional imaging techniques have become routinely used, portable US devices have been available in the market. In addition, standardization studies related with performer education have increased. Therefore, in our opinion, US will be in routine use for the purpose of both planning and practice of the interventions in algology clinics in the near future.

\section{Conflict-of-interest issues regarding the authorship or article: None declared.}

\section{Peer-rewiew: Externally peer-reviewed.}

\section{References}

1. Giordano BD, Baumhauer JF, Morgan TL, Rechtine GR. Cervical spine imaging using standard C-arm fluoroscopy: patient and surgeon exposure to ionizing radiation. Spine (Phila Pa 1976) 2008;33(18):1970-6. CrossRef

2. Finlayson RJ, Etheridge JP, Vieira L, Gupta G, Tran DQ. A ran- domized comparison between ultrasound- and fluoroscopy-guided third occipital nerve block. Reg Anesth Pain Med 2013;38(3):212-7. CrossRef

3. Obernauer J, Galiano K, Gruber H, Bale R, Obwegeser AA, Schatzer R, et al. Ultrasound-guided versus Computed Tomography-controlled facet joint injections in the middle and lower cervical spine: a prospective randomized clinical trial. Med Ultrason 2013;15(1):10-5. CrossRef

4. Narouze SN, Vydyanathan A, Kapural L, Sessler DI, Mekhail $\mathrm{N}$. Ultrasound-guided cervical selective nerve root block: a fluoroscopy-controlled feasibility study. Reg Anesth Pain Med 2009;34(4):343-8. CrossRef

5. Cohen SP, Strassels SA, Kurihara C, Forsythe A, Buckenmaier CC 3rd, McLean B, et al. Randomized study assessing the accuracy of cervical facet joint nerve (medial branch) blocks using different injectate volumes. Anesthesiology 2010;112(1):144-52. CrossRef

6. Narouze SN. Ultrasound-guided interventional procedures in pain management: Evidence-based medicine. Reg Anesth Pain Med 2010;35(2 Suppl):55-8. CrossRef

7. Martinoli C, Bianchi S, Santacroce E, Pugliese F, Graif M, Derchi LE. Brachial plexus sonography: a technique for assessing the root level. AJR Am J Roentgenol 2002;179(3):699702. crossRef

8. Bruneau M, Cornelius JF, Marneffe V, Triffaux M, George B. Anatomical variations of the V2 segment of the vertebral artery. Neurosurgery 2006;59(1 Suppl 1):ONS20-4; discussion ONS20-4.

9. Narouze SN, Provenzano DA. Sonographically guided cervical facet nerve and joint injections: why sonography? J Ultrasound Med 2013;32(11):1885-96. CrossRef

10. Narouze S. Ultrasound-guided cervical facet intraarticular injections. Tech Reg Anesth Pain Manage 2009;13:133-6.

11. Narouze S, Peng PW. Ultrasound-guided interventional procedures in pain medicine: a review of anatomy, sonoanatomy, and procedures. Part II: axial structures. Reg Anesth Pain Med 2010;35(4):386-96. CrossRef

12. Eichenberger U, Greher M, Kapral S, Marhofer P, Wiest R, Remonda $L$, et al. Sonographic visualization and ultrasoundguided block of the third occipital nerve: prospective for a new method to diagnose C2-C3 zygapophysial joint pain. Anesthesiology 2006;104(2):303-8. CrossRef

13. Finlayson RJ, Etheridge JP, Vieira L, Gupta G, Tran DQ. A randomized comparison between ultrasound- and fluoroscopy-guided third occipital nerve block. Reg Anesth Pain Med 2013;38(3):212-7. CrossRef

14. Gofeld M, Bhatia A, Abbas S, Ganapathy S, Johnson M. Development and validation of a new technique for ultrasound-guided stellate ganglion block. Reg Anesth Pain Med 2009;34(5):475-9. CrossRef

15. Narouze S. Ultrasound-guided stellate ganglion block: safety and efficacy. Curr Pain Headache Rep 2014;18(6):424.

16. Groeben $\mathrm{H}$. Epidural anesthesia and pulmonary function. J Anesth 2006;20(4):290-9. CrossRef

17. Gray H. Anatomy of the Human Body, 20th ed. Philadelphia: Lea \& Febiger; 1918; Bartleby.com, 2000. Available from URL: http://www.bartleby.com/107/. 
18. Broadbent CR, Maxwell WB, Ferrie R, Wilson DJ, GawneCain M, Russell R. Ability of anaesthetists to identify a marked lumbar interspace. Anaesthesia 2000;55(11):11226. CrossRef

19. Arzola C, Avramescu S, Tharmaratnam U, Chin KJ, Balki M. Identification of cervicothoracic intervertebral spaces by surface landmarks and ultrasound. Can J Anaesth 2011;58(12):1069-74. CrossRef

20. Carnie J, Boden J, Gao Smith F. Prediction by computerised tomography of distance from skin to epidural space during thoracic epidural insertion. Anaesthesia 2002;57(7):701-4.

21. Avramescu S, Arzola C, Tharmaratnam U, Chin KJ, Balki M. Sonoanatomy of the thoracic spine in adult volunteers. Reg Anesth Pain Med 2012;37(3):349-53. CrossRef

22. American Society of Anesthesiologists Task Force on Chronic Pain Management; American Society of Regional Anesthesia and Pain Medicine. Practice guidelines for chronic pain management: an updated report by the American Society of Anesthesiologists Task Force on Chronic Pain Management and the American Society of Regional Anesthesia and Pain Medicine. Anesthesiology 2010;112(4):810-33. CrossRef

23. Karmakar MK, Li X, Ho AM, Kwok WH, Chui PT. Realtime ultrasound-guided paramedian epidural access: evaluation of a novel in-plane technique. $\mathrm{Br} J$ Anaesth 2009;102(6):845-54. CrossRef

24. Karmakar MK, Li X, Kwok WH, Ho AM, Ngan Kee WD. Sonoanatomy relevant for ultrasound-guided central neuraxial blocks via the paramedian approach in the lumbar region. Br J Radiol 2012;85(1015):262-9. CrossRef

25. Sahota JS, Carvalho JC, Balki M, Fanning N, Arzola C. UItrasound estimates for midline epidural punctures in the obese parturient: paramedian sagittal oblique is comparable to transverse median plane. Anesth Analg 2013;116(4):829-35. CrossRef

26. Evansa I, Logina I, Vanags I, Borgeat A. Ultrasound versus fluoroscopic-guided epidural steroid injections in patients with degenerative spinal diseases: a randomised study. Eur J Anaesthesiol 2015;32(4):262-8. CrossRef

27. Küllmer K, Rompe JD, Löwe A, Herbsthofer B, Eysel P. UItrasound image of the lumbar spine and the lumbosacral transition. Ultrasound anatomy and possibilities for ultrasonically-controlled facet joint infiltration. [Article in German] Z Orthop Ihre Grenzgeb 1997;135(4):310-4. [Abstract] CrossRef

28. Gofeld M, Bristow SJ, Chiu S. Ultrasound-guided injection of lumbar zygapophyseal joints: an anatomic study with fluoroscopy validation. Reg Anesth Pain Med 2012;37(2):228-31. CrossRef

29. Galiano K, Obwegeser AA, Walch C, Schatzer R, Ploner F, Gruber $\mathrm{H}$. Ultrasound-guided versus computed tomography-controlled facet joint injections in the lumbar spine: a prospective randomized clinical trial. Reg Anesth Pain Med 2007;32(4):317-22. CrossRef

30. Greher M, Kirchmair L, Enna B, Kovacs P, Gustorff B, Kapral $S$, et al. Ultrasound-guided lumbar facet nerve block: accuracy of a new technique confirmed by computed tomography. Anesthesiology 2004;101(5):1195-200. CrossRef

31. Shim JK, Moon JC, Yoon KB, Kim WO, Yoon DM. Ultrasoundguided lumbar medial-branch block: a clinical study with fluoroscopy control. Reg Anesth Pain Med 2006;31(5):4514. CrossRef

32. Rauch S, Kasuya Y, Turan A, Neamtu A, Vinayakan A, Sessler DI. Ultrasound-guided lumbar medial branch block in obese patients: a fluoroscopically confirmed clinical feasibility study. Reg Anesth Pain Med 2009;34(4):340-2.

33. Simpson G, Nicholls B. Use of ultrasound in chronic pain medicine. Part 1: neuraxial and sympathetic blocks. Cont Educ Anaesth, Crit Care \& Pain 2013;13(5):145. CrossRef

34. Loizides A, Gruber H, Peer S, Brenner E, Galiano K, Obernauer J. A new simplified sonographic approach for pararadicular injections in the lumbar spine: a CT-controlled cadaver study. AJNR Am J Neuroradiol 2011;32(5):828-31.

35. Loizides A, Gruber H, Peer S, Galiano K, Bale R, Obernauer J. Ultrasound guided versus CT-controlled pararadicular injections in the lumbar spine: a prospective randomized clinical trial. AJNR Am J Neuroradiol 2013;34(2):466-70.

36. Blanchais A, Le Goff B, Guillot P, Berthelot JM, Glemarec $J$, Maugars Y. Feasibility and safety of ultrasound-guided caudal epidural glucocorticoid injections. Joint Bone Spine 2010;77(5):440-4. CrossRef

37. Pekkafahli MZ, Kiralp MZ, Başekim CC, Silit E, Mutlu H, Oztürk E, et al. Sacroiliac joint injections performed with sonographic guidance. J Ultrasound Med 2003;22(6):553-9.

38. Klauser A, De Zordo T, Feuchtner G, Sögner P, Schirmer $M$, Gruber J, et al. Feasibility of ultrasound-guided sacroiliac joint injection considering sonoanatomic landmarks at two different levels in cadavers and patients. Arthritis Rheum 2008;59(11):1618-24. CrossRef

39. Maurits NM, Bollen AE, Windhausen A, De Jager AE, Van Der Hoeven JH. Muscle ultrasound analysis: normal values and differentiation between myopathies and neuropathies. Ultrasound Med Biol 2003;29(2):215-25. CrossRef 